\author{
Дьяченко Ю.В. \\ старший викладач \\ кафедра менеджменту та логістики \\ Одеська національна академія харчових технологій \\ вул. Канатна, 112, м. Одеса, Україна, 65039 \\ E-mail: ypogarchuk@gmail.com
}

\title{
ПРАВОВЕ ЗАБЕЗПЕЧЕННЯ КОНКУРЕНТОСПРОМОЖНОСТІ ПРОДУКЦІЇ МЯСОПЕРЕРОБНИХ ПІДПРИЄМСТВ УКРАЇНИ НА ЄВРОПЕЙСЬКОМУ РИНКУ
}

В статті розглянуто структуру експорту агропромислової продукції та зміни в географії експортних потоків з України. Проаналізовано можливість вітчизняних підприємств харчової промисловості, в тому числі м'ясопереробної галузі, бути конкурентоспроможними на зовнішньому ринку, зокрема ринку Європейського союзу. Освітлено питання державного регулювання якості та безпечності харчової продукції в Україні.

Ключові слова: м'ясопереробна галузь, конкурентоспроможність, стратегія, безпека продукції, система НАССР, державне регулювання.

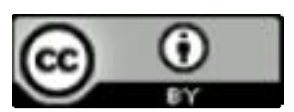

This work is licensed under a Creative Commons Attribution 4.0 International License http://creativecommons.org/licenses/by/4.0/
Постановка проблеми та її зв'язок з важливими науковими та практичними завданнями. Сучасні умови розвитку економіки країни вимагають інтеграції вітчизняних виробників в систему світових товарних ринків. Харчова промисловість, в тому числі і м'ясопереробна галузь, є одним з найважливіших секторів економіки України. Але для того, щоб бути конкурентоспроможними i на іноземних ринках, м'ясопереробним підприємствам необхідно відповідати певним вимогам світових стандартів якості та безпечності.

Аналіз останніх публікацій по проблемі. Дослідженню умов функціонування м'ясопереробних підприємств присвячені праці таких вітчизняних учених-економістів, як Заремба П.О. [1], Драган О.І. [2], Міхєєнко К.С. [3], Мазуренко О.В. [4] та ін. В умовах вступу України до СОТ, членства в СС та зміні зовнішньої експортної політики держави особливого значення набувають питання забезпечення конкурентоспроможності та безпечності м'ясопереробних підприємств. Отже, подальші дослідження і розробка пропозицій, щодо підвищення конкурентоспроможності вітчизняних м'ясопереробних підприємств на міжнародному рівні є актуальними.

Формулювання цілей дослідження. Метою даного дослідження $€$ аналіз географії експортних потоків з України, виявлення відповідності продукції вітчизняних м'ясопереробних підприємств вимогам європейського ринку та їх конкурентоспроможності.

Виклад основних результатів та їх обгрунтування. Економічна криза Україні негативно впливає на стан зовнішньої торгівлі, в тому числі на експорт товарів та його структуру. До числа експортних товарів, за якими відбулося найменше скорочення відноситься агропродовольча продукція. В іï структурі станом на 2016 р. більшу частину складають різні види сільськогосподарської продукції - 8870 млн. дол. (58 \%), в той час як доля експорту продукції харчової промисловості 3 більшою доданою вартістю знаходиться на рівні 6414 млн. дол. (42 \%) [5]. Що стосується географії експортних потоків агропродовольчої продукції то як свідчать дані тут відбуваються серйозні зміни (табл. 1). Дані табл. 1 свідчать, що експорт в країни СНД суттєво скоротився по причині зменшення поставок у Російську Федерацію. Другим за обсягом експорту з України є Свропейський Союз. Інші країни світу - передусім країни Азії та Африки вже тривалий час $є$ головними покупцями агропродовольчої продукції з практично стабільно зростаючим з року в рік обсягом.

Географія експорту агропродовольчої продукції *

\begin{tabular}{|l|c|c|c|c|}
\hline \multirow{2}{*}{ Напрям експорту } & \multicolumn{2}{|c|}{2013 рік } & \multicolumn{2}{c|}{2016 рік } \\
\cline { 2 - 5 } & млн. дол. & $\%$ & млн. дол. & $\%$ \\
\hline 1. СНД & 3611 & 21,3 & 1146 & 7,5 \\
\hline 2. СС & 4485 & 26,5 & 4122 & 26,4 \\
\hline 3. Інші країни світу & 8834 & 52,2 & 10016 & 66,1 \\
\hline Всього & $\mathbf{1 6 9 3 0}$ & $\mathbf{1 0 0}$ & $\mathbf{1 5 2 8 4}$ & $\mathbf{1 0 0}$ \\
\hline
\end{tabular}

* розраховано автором за даними Державної служби статистики України [6] 
Багаторічна орієнтація експорту на країни СНД виявилась хибною стратегією, отже, виправлення ситуації в секторі агропродовольчого експорту в Україні залежить від того, наскільки швидко будуть розвиватися переробні галузі та, наскільки вітчизняна вироблена продукція буде відповідати світовим стандартам.

В умовах глобалізації та асоціації в СС значно зросла конкурентна боротьба за споживача. Це стосується як внутрішнього, так і зовнішнього ринку, що вимагає виконання певних вимог, таких як: перехід на міжнародні стандарти якості, інноваційний розвиток підприємств галузі, екологічність та безпечність продукції, впровадження комплексної переробки сировини, ресурсозбереження та ін.

В м'ясопереробній промисловості України ми спостерігаємо процес розширення й концентрації виробничих потужностей. Все більшу вагу починають займати великі виробники, що орієнтуються на потреби споживачів і забезпечують безпеку та належну якість м'ясної продукції. В рейтингу найбільших м'ясопереробних підприємств України перші місця посіли: ТОВ «М'ясна фабрика «Фаворит плюс», ТОВ «Глобінський м'ясокомбінат», ВАТ «М'ясокомбінат «Ятрань», ПАТ «МХП» [7]. Ці підприємства є лідерами галузі і входять в вертикально-інтегровані структури. Майже у всіх з перерахованих, виробництва сертифіковані за стандартами ISO 9001, 22000. Саме ці два фактори є запорукою успіху, адже це дає їм можливість задовольняти потреби українських споживачів маючи якісну, безпечну сировину для виробничого процесу, що робить підприємства конкурентоспроможними на внутрішньому та на інших ринках [8].

Євроінтеграційний процес, який почався в країни, передусім, вимагає від суб'єктів господарювання застосування міжнародних стандартів та норм ведення бізнесу. Впровадження в діяльність підприємств сертифікації продукції за системою ISO стає нормою ведення бізнесу для все більшого кола підприємств. Дослідження показало, що на європейському ринку та США, окрім поняття «якості», існує поняття «безпечності». Поняття безпечний харчових продукт визначається як «продукт, який не справляє шкідливого впливу на здоров'я людини та є придатним для споживання» [3].

В Україні безпечність харчової продукції регулюється такими документами: технічні регламенти, стандарти, санітарні правила і норми, Постанови Кабінету міністрів України, накази відповідних міністерств та відомств. Поняття «безпечність» $є$ базовим у системі управління ризиками підприємств харчової галузі (Hazard Analysis and Critical Control Points), мета якої полягає у виявлені критичних точок та факторів, які впливають на безпечність готового продукту, в усуненні, виявлених безпечних факторів та постійному контролю за виробництвом продукції підприємств харчової галузі, зокрема, м'ясопереробних.

У дослідженні [9] визначено, що «впровадження систем управління безпечністю харчових продуктів, заснованих на принципах НАССР, інтен- сивно розпочалось після прийняття Директиви про гігієну харчових продуктів. Головний акцент зроблено на те, що, у кожній країні СС було розроблено національні регламенти і стандарти. Контроль виконання вимог НАССР покладено на уповноважені урядом органи».

Закон України «Про основні принципи та вимоги до безпечності та якості харчових продуктів» [10], регулює правовідносини відносини між державою, виробниками харчової продукції, продавцями та споживачами. Він передбачає загальнодержавну концепцію впровадження принципів НАССР. Закон передбачає адаптацію законодавства України відповідно до вимог ЄС щодо сфери безпечності та якості харчових продуктів та регламентує механізм поетапного впровадження систем управління безпечністю харчових продуктів на підприємствах харчової промисловості, зокрема, м'ясопереробної.

Регламент СС №852/2004 з 1 січня 2006 р. встановлює, що «НАССР є обов'язковою для європейських виробників харчових продуктів та кормів», дані вимоги діють і на експортерів харчової продукції, у т.ч. $з$ України. Для отриманням міжнародного ветеринарного сертифікату українські виробники м'яса та м'ясопродуктів повинні мати дієву систему НАССР. Отримання, зазначеного сертифікату $\square$ обов'язкова умова експорту. В Україні діють декілька добровільних стандартів, які виробники можуть застосовувати. До них відносяться стандарт ДСТУ 4161-2003 «Системи управління безпечністю харчових продуктів. Вимоги» та стандарти ISO серії 22000.

Закон України «Про основні принципи та вимоги до безпечності та якості харчових продуктів» висуває вимоги щодо механізму впровадження принципів системи НАССР. Ці вимоги висуваються до підприємств, продукція яких у своєму складі містить сировину тваринного походження. На сам перед це м'ясокомбінати та бійні, а також молокозаводи. Як зазначено в Законі «НАССР упроваджується на потужностях, які провадять діяльність із харчовими продуктами, у складі яких є необроблені інгредієнти тваринного походження (необроблене молоко, м'ясо, риба, молюски і ракоподібні, зокрема свіжі, охолоджені або заморожені, яйця, мед, їхні похідні та інші продукти, виготовлені з частин тварин, окремих їхніх органів та/або тканин, призначені для споживання людиною)» [11]. До 2018 року механізм впровадження НАССР повинні здійснити кондитерські фабрики, підприємства 3 переробки й виробництва овочефруктової продукції та строком до 2019 року система НАССР повинна бути впроваджена на малих підприємствах.

На Державну службу України з питань безпечності харчових продуктів та прав споживачів, яка створена на базі ветеринарної і фіто санітарної служби, інспекції із захисту прав споживачів, та санепідемслужби, покладено контроль за виконанням норми Закону підприємствами-виробниками. Постановою КМУ від 2 вересня 2015 року № 667 затверджено «Положення про Держпродспоживслужбу» [12], згідно якого дана служба «...це центральний орган 
виконавчої влади, діяльність якої спрямовується i координується Кабінетом Міністрів України через Міністра аграрної політики та продовольства». За невиконання Закону, встановлено штрафні санкції для юридичних та фізичних осіб, а саме:

юридичні особи - від 30 до 75 мінімальних заробітних плат,

фізичні особи-підприємці - від 3 до 15 мінімальних заробітних плат та загроза зупинення роботи виробничих потужностей.

У Наказі Міністерства аграрної політики та продовольства України № 590 від 01.10.2012 р. сказано, що застосування системи НАССР полягає в «ідентифікації можливих небезпечних факторів; встановленні того, де і як небезпечні фактори можуть бути усунуті, попереджені або приведені до прийнятного рівня; розробці відповідних заходів і навчання персоналу; впровадженні заходів на практиці та документування процедур» [13].

Отже, можемо констатувати, що згідно до наказу МінАПК №590, система НАССР має охоплювати наступні процеси: «планування та розміщення виробничих, допоміжних та побутових приміщень згідно вимог ДСТУ, для усунення перехресного забруднення; жорсткі вимоги до стану приміщень, проведення ремонтних робіт, ТО обладнання 3 дотримання санітарних норм, а також постійний контроль стосовно захисту харчових продуктів від забруднення та сторонніх домішок; вимоги до планування і стану всіх комунікацій; безпечність води, льоду, пари, допоміжних матеріалів для переробки харчових продуктів, предметів та матеріалів, які контактують із продуктами; процедури прибирання, миття і дезінфекції виробничих, допоміжних і побутових приміщень та інших поверхонь; здоров'я та гігієна персоналу; своєчасна утилізація відході виробництва та сміттям; боротьба зі шкідниками; жорсткі вимоги до якості сировини та постійний контроль за умовами ії̈ постачання; зберігання і транспортування; контроль за виконанням всіх умов технологічного процесу; маркування харчових продуктів та поінформованість споживачів» [13].

Впровадження системи НАССР на м'ясопереробних підприємствах країни потребує виконання наступних кроків:

1) розробка плану НАССР.

«План НАССР - це документ, підготовлений відповідно до принципів НАССР для забезпечення контролю за небезпечними факторами, які є визначальними для безпечності харчових продуктів на тому етапі харчового ланцюга, який розглядається» [11].

У проектну групу входять працівники різні підрозділи, від діяльності яких залежить безпечність продуктів, та які мають знання про технологічні процеси та досвід роботи, у цьому напрямі. За необхідністю, на етапі розробки залучають зовнішніх експертів, які мають поглиблені знання про небезпечні фактори, характерні для харчових продуктів, технологічні процеси та принципи НАССР.

2) Наявність щонайменше однієї людини, яка пройшла спеціальне навчання із застосування цієї системи.

В Україні нині є компанії, які надають послуги 3 навчання персоналу чи працівників, котрі відповідатимуть за функціонування НАССР на підприємстві. Мінагропрод і Держпродспоживслужбі надаються відповідні консультації підприємствам. HACCP.

3) наявність програм-передумов системи

«Програма-передумова - це основні умови та види діяльності, які є необхідними для підтримання гігієнічних умов на всіх етапах ланцюга виготовлення харчових продуктів» [10,11].

Сертифікація постійно діючих процедур, заснованих на принципах системи аналізу небезпечних факторів та контролю у критичних точках, не $\epsilon$ обов'язковою. Обов'язковою $\epsilon$ наявність Програмпередумов системи НАССР

Висновки та перспективи подальших досліджень. В структурі агропромислової продукції доля експорту продукції харчової промисловості 3 більшою доданою вартістю складає 42 \% від загальної кількості продукції. В той же час, найбільшими покупцями є країни Азії та Африки, далі за обсягом йде Європейський Союз і найменше експортується в країни СНД. Така географія експорту вимагає від вітчизняних виробників м'ясопереробної галузі відповідності світовим стандартам якості та безпечності продукції. Це положення реалізується за допомогою впровадження системи стандартів якості ISO та систем управління безпечністю харчових продуктів, заснованих на принципах НАССР. Загальнодержавну концепцію впровадження принципів НАССР реалізує Закон України «Про основні принципи та вимоги до безпечності та якості харчових продуктів», виконання якого контролює Держпродспоживслужба.

\section{Література}

1. Заремба П. О. Реалізація потенційних можливостей підприємств як умова стабілізації та ефективного розвитку м'ясопереробної промисловості України / П. О. Заремба // Наук. вісн. Херсон. держ. ун-ту, 113 Торгівля і ринок України. - 2010. - Вип. 29. - С. 403-410.

2. Драган О. І. Забезпечення конкурентоспроможності підприємств м'ясної промисловості України : автореф. дис. на здобуття наук. ступеня канд. ек. наук : спец. 08.00.04 «Економіка та управління підприємствами (за видами економічної діяльності)» / Драган О. І. - Київ, 2008. - 37 с.

3. Міхєєнко К. С Стратегія економічного розвитку м'ясопереробної промисловості : автореф. дис. на здобуття наук. ступеня канд. ек. наук : спец. 08.00.03 «Економіка та управління національним господарством» / Міхєєнко К. С. - Донецьк, 2007. - 20 с. 
4. Мазуренко О.В. Стан і напрями розвитку м'ясопродуктового підкомплексу в Україні / О.В. Мазуренко // Економіка АПК. - 2012. - № 8. - С. 59-65.

5. Антонюк О.П.; Антонюк П.О.; Лисюк В.М. Аналіз динаміки та структури експорту агропродовольчої продукції // Економіка харчової промисловості. - 2017. - Т. 9, Вип. 3. - С. 8-15; DOI: 10.15673/fie.v9i3.619

6. Державна служба статистики України [Електронний ресурс]. - Режим доступу: http: //www.ukrstat.gov.ua.

7. Рейтинг ТОП-100: крупнейшие производители мясной продукции [Електронний ресурс]. - Режим доступу: https://delo.ua/business

8. Шелест Н.А. Моніторинг стану, проблем та перспектив розвитку м'ясопереробних підприємств України // Вісник ОНУ ім. І. І. Мечникова. - 2014. - Т. 19, Вип.1/2. - С. 47-50.

9. Дьяченко Ю. В. Безпечність харчової продукції, як фактор конкурентоспроможності підприємств м'ясопереробної галузі України // Економічні та соціальні аспекти розвитку України на початку XXI століття : V міжнар. наук.-практ. конф., 12-13 жовтня 2017 р.: тези доповіді. - Одеса: ОНАХТ, 2017. - C. 127-129.

10. Закон України «Про основні принципи та вимоги до безпечності та якості харчових продуктів» № 771/97-ВР від 23.12.1997: за станом на 05.07.2017p. [Електронний ресурс]. - Режим доступу: http://zakon3.rada.gov.ua/laws/show/771/97-\%D0\%B2\%D1\%80

11. Два роки дедлайну - що потрібно зробити АПК для переходу на систему НАССР [Електронний ресурс]. - Режим доступу: https://agropolit.com/spetsproekty.

12. Постанова Кабінету Міністрів України № 667 від 02.09.2015 «Про затвердження Положення про Державну службу України 3 питань безпечності харчових продуктів та захисту споживачів»: станом на 13.01.2017p. [Електронний ресурс]. - Режим доступу: http://zakon2.rada.gov.ua/laws/show/667-2015-\%D0\%BF

13. Наказ міністерства аграрної політики та продовольства України №590 від 01.10.2012 «Про затвердження Вимог щодо розробки, впровадження та застосування постійно діючих процедур, заснованих на принципах Системи управління безпечністю харчових продуктів (НАССР)» : за станом на 25.12.2015р. [Електронний ресурс]. - Режим доступу: http://zakon3.rada.gov.ua/laws/show/z1704-12

Стаття надійшла 05.10.2017

Стаття прийнята до друку 19.10.2017

Доступно в мережі Internet 30.12.2017

\author{
Дьяченко Ю.В. \\ старший преподаватель \\ кафедра менеджмента и логистики \\ Одесская национальная академия пищевых технологий \\ ул. Канатная, 112, г. Одесса, Украина, 65039 \\ E-mail: ypogarchuk@gmail.com
}

\title{
ПРАВОВОЕ ОБЕСПЕЧЕНИЕ КОНКУРЕНТОСПОСОБНОСТИ ПРОДУКЦИИ МЯСОПЕРЕРАБАТЫВАЮЩИХ ПРЕДПРИЯТИЙ УКРАИНЫ НА ЕВРОПЕЙСКОМ РЫНКЕ
}

В статье рассмотрена структура экспорта агропромышленной продукции и изменения в географии экспортных потоков из Украины. Как показывает исследование, объёмы экспорта в страны СНГ и Европейского союза в 2016 году значительно отличаются от 2013 года. Экспорт в страны СНГ сократился по причине снижения поставок в Росийскую Федерацию и составляет 7,5\%, на рынок Европейского союза экспортируется 21,6\% от объёма экспорта агропромышленной продукции. Для того, чтобы отечественная продукция пищевой промышленности, в том числе мясоперерабатывающей отрасли, была конкурентоспособной на иностранных рынках европейских стран, она должна соответствовать определенным требованиям стандартов качества и безопасности. В работе была проанализирована законодательная база Украины, регулирующая качество и безопасность пищевой продукции, на предмет ее соответствия требованиям Европейского союза. Было выявлено, что основным регламентирующим документом является Закон Украины «Об основных принципах и требования к безопасности и качеству пищевых продуктов». Он регулирует правоотношения отношения между государством, производителями пищевой продукции, продавцами и потребителями. Данный закон предусматривает общегосударственную концепцию внедрения принципов НАССР и адаптацию законодательства Украины в соответствии с требованиями EC относительно сферы безопасности и качества пищевых продуктов, а также регламентирует механизм поэтапного внедрения систем управления безопасностью пищевых продуктов на предприятиях пищевой промышленности. Применение системы 
НАССР заключается в идентификации возможных опасных факторов; установлении того, где и как опасные фракторы могут быть устранены, предупреждены или приведены до приемлемого уровня; разработке соответствующих мер и обучение персонала; внедрении мероприятий на практике и документирования процедур. Внедрение этой системы является обязательным для каждого пищевого предприятия Украины, так как позволяет получить конкуреноспособную продукцию так как позволяет получить продукцию конкуреноспособную в странах Европейского союза.

Ключевые слова: мясоперерабатывающая отрасль, конкурентоспособность, стратегия, безопасность, система НАССР, государственное регулирование.

\author{
Diachenko Y. \\ Assistant \\ Department of Management and Logistics \\ Odessa National Academy of Food Technologies \\ Kanatna str., 112, Odesa, Ukraine, 65039 \\ E-mail: ypogarchuk@gmail.com
}

\title{
LEGAL ENFORCEMENT OF THE COMPETITIVENESS OF THE MEAT-PROCESSING ENTERPRISES PRODUCTS IN THE EUROPEAN MARKET
}

The article examines the structure of agro-industrial products exports and changes in the geography of export flows from Ukraine. As the research shows, the volume of exports to the CIS countries, as well as to the European Union countries in 2016 significantly differs from the year of 2013. Exports to the CIS countries have decreased due to a drop in supplies to the Russian Federation and now it is $7.5 \%$, the export to the European Union market is $21.6 \%$ of the agro-industrial products exports volume. In order to be competitive in foreign markets of European countries, the domestic products of the food industry including meat processing industry must meet certain requirements of quality and safety standards. This paper provides analysis of the legislative base of Ukraine which regulates the quality and safety of food products to ensure consistency with the requirements of the European Union. It was revealed that the main regulatory document is the Law of Ukraine "On Basic Principles and Requirements for Safety and Quality of Food Products". It regulates the legal relationship between the state, food producers, sellers and consumers. This law provides for a national concept for the implementation of HACCP principles and the adaptation of Ukrainian legislation in accordance with EU requirements for food safety and quality, and it regulates the mechanism for the phased implementation of food safety management systems at food industry enterprises. The application of the HACCP system is designed to identify possible hazards; to show where and how the hazards can be eliminated, alerted or brought to an acceptable level; to develop the appropriate measures and staff training; to implement these measures in practice and to document the procedures. The implementation of this system is mandatory for every food enterprise in Ukraine, as it allows obtaining products that are competitive in the European Union countries. regulation.

Key words: meat processing industry, competitiveness, strategy, security, HACCP system, state

\section{References}

1. Zaremba, P. O. (2010). Realizatsiia potentsiinykh mozhlyvostei pidpryiemstv yak umova stabilizatsii ta efektyvnoho rozvytku m'iasopererobnoi promyslovosti Ukrainy. Torhivlia i rynok Ukrainy, (29), 403-410.

2. Drahan, O. I. (2008). Zabezpechennia konkurentospromozhnosti pidpryiemstv m'iasnoi promyslovosti Ukrainy. Kyiv.

3. Mikhieienko, K. S. (2007). Stratehiia ekonomichnoho rozvytku m'iasopererobnoi promyslovosti. Donetsk.

4. Mazurenko, O. V. (2012). Stan i napriamy rozvytku m'iasoproduktovoho pidkompleksu v Ukraini. Ekonomika APK, (8), 59-65.

5. Antoniuk, O. P., Antoniuk, P. O., \& Lysiuk, V. M. (2017). Analiz dynamiky ta struktury eksportu ahroprodovolchoi produktsii. Ekonomika kharchovoi promyslovosti, 9(3), 8-15. doi:10.15673/fie.v9i3.619

6. Derzhavna sluzhba statystyky Ukrainy. (2017). Retrieved from http://www.ukrstat.gov.ua

7. Reitynh TOP-100: krupneishye proyzvodytely miasnoi produktsyy. (2017). Retrieved from https://delo.ua/business 
8. Shelest, N. A. (2014). Monitorynh stanu, problem ta perspektyv rozvytku m'iasopererobnykh pidpryiemstv Ukrainy. Visnyk ONU im. I. I. Mechnykova, 19(1/2), 47-50.

9. Diachenko, Iu. V. (2017). Bezpechnist kharchovoi produktsii, yak faktor konkurentospromozhnosti pidpryiemstv m'iasopererobnoi haluzi Ukrainy. In Ekonomichni ta sotsialni aspekty rozvytku Ukrainy na pochatku XXI stolittia: V mizhnar. nauk.-prakt. konf. (pp. 127-129). Odesa: ONAKhT.

10. Zakon Ukrainy «Pro osnovni pryntsypy ta vymohy do bezpechnosti ta yakosti kharchovykh produktiv» № 771/97-VR vid 23.12.1997: $\mathrm{za}$ stanom na 05.07.2017r. (2017). Retrieved from http://zakon3.rada.gov.ua/laws/show/771/97-\%D0\%B2\%D1\%80

11. Dva roky dedlainu - shcho potribno zrobyty APK dlia perekhodu na systemu HACCP. (2017, August 01). Retrieved from https://agropolit.com/spetsproekty

12. Postanova Kabinetu Ministriv Ukrainy № 667 vid 02.09.2015 «Pro zatverdzhennia Polozhennia pro Derzhavnu sluzhbu Ukrainy z pytan bezpechnosti kharchovykh produktiv ta zakhystu spozhyvachiv»: stanom na 13.01.2017 r. (2017). Retrieved from http://zakon2.rada.gov.ua/laws/show/667-2015-\%D0\%BF

13. Nakaz ministerstva ahrarnoi polityky ta prodovolstva Ukrainy № 590 vid 01.10.2012 «Pro zatverdzhennia Vymoh shchodo rozrobky, vprovadzhennia ta zastosuvannia postiino diiuchykh protsedur, zasnovanykh na pryntsypakh Systemy upravlinnia bezpechnistiu kharchovykh produktiv (NASSR)»: za stanom na 25.12.2015r. (2015). Retrieved from http://zakon3.rada.gov.ua/laws/show/z1704-12

Received 5 October 2017 Approved 19 October 2017 Available in Internet 30.12.2017 